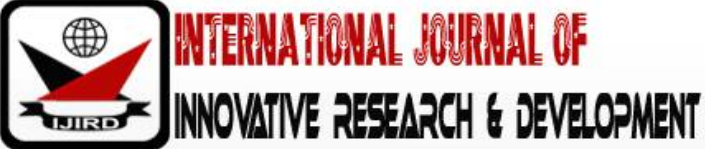

ISSN 2278 - 0211 (Online)

\section{Comparative Assessment of Pipe-Borne Water and Groundwater Quality and Their Health Implication in Gwagwalada Town, Nigeria}

Dr. Makwe Edith
Senior Lecturer, Department of Geography and Environmental Management,
University of Abuja, Nigeria
Adeleke Taiwo Samuel
Research Student, Department of Geography and Environmental Management,
University of Abuja, Nigeria
Olanrewaju Odunayo
Research Student, Department of Geography and Environmental Management,
University of Abuja, Nigeria

\begin{abstract}
:
The study aimed to comparatively assess pipe-borne water and groundwater quality in Gwagwalada town and their health implication, by collecting three pipe-borne water and five groundwater samples from selected points at Phases 1 , 2, 3, Ungwan Dodo, Ungwan Shanu and Dagiri and analyzing them for parameters such as pH, EC, DO, Hardness, Total Chlorine, Chloride, Nitrate, Ammonia, Sulphate, Phosphate, Fe, $\mathrm{Pb}, \mathrm{Zn}, \mathrm{Cu}, \mathrm{Cd}, \mathrm{Mn}$, Al and Total coliform count. Concentration of analysed parameters for the pipe-borne water samples were compared with those of the groundwater samples and both were also compared with WHO and FME.T-test was used to test the hypothesis that there is no significant difference in concentrations of the analysed parameters between pipe-borne water and groundwater samples. Result of the study showed that the concentration of most of the parameters are higher in the groundwater than in the pie-borne water samples. Parameters such as $\mathrm{pH}, \mathrm{EC}$, Total hardness, sulphate, phosphate, ammonia and copper for both pipe-borne water and groundwater samples were within WHO/FME standards, while manganese and faecal coli forms are higher than the standards across all samples. Chloride, nitrate, cadmium, iron, zinc and aluminium are higher than the standard in groundwater samples. Total chlorine has higher concentration in pipe-borne water samples while Lead has elevated concentration in PB2, PB3, GW3, GW4 and GW5. T-test results showed that there is significant difference in the concentrations of analysed parameters between pipe-borne water and groundwater sample. The study concludes that the groundwater is more polluted than the pipe-borne water and that the continuous consumption of the groundwater without pre-treatment may have adverse health implications. The study recommends among other things, the location of wells and boreholes away from areas where human activities can pollute them; and the provision of simple and affordable water purifiers in the study area.
\end{abstract}

Keywords: Pipe-borne, groundwater, water quality, health implication, pollution

\section{Introduction}

Water is a natural resource of fundamental importance. This is because it supports all forms of life and creates jobs and wealth in the water sector, tourism, recreation and fisheries (Ntengwe, 2005). Without water, life as it exists on our planet, is impossible (Akpabio,2012). Potable or drinking water is defined as having acceptable quality in terms of its physical, chemical and bacteriological parameters, so that it can be safely used for drinking and cooking (WHO, 2004).

The Nigerian government has long considered the provision of water supply and sanitation services to be in the domain of the Federal, State and Local Government through the Water Board Authorities. The Federal Government is in charge of water resources management; the state government has the primary responsibility for urban water supply; and local governments together with communities are responsible for rural water supply (WHO/UN-Water, 2015). However, the public sector has not been successful in meeting more than a small part of the demand for water of residential and commercial users (Afolabi et al., 2012). This is due to population increase (Makwe, 2013), deterioration of the necessary infrastructure and poor management of the system. Many water supply systems show extensive deterioration and poor utilization of the existing capacities, due to under-maintenance and lack of funds for operation (Yusuf, 2007). The deterioration of the pipe-borne water infrastructures has not only resulted in the shortage of potable water supply, but has also affected the quality of the water adversely. Hence pipe-borne water, like water from other sources, does not attain 
hundred percent purity (Emoabino and Alayande, 2007). Many households therefore depend on other sources of water supply, especially groundwater through hand dug wells and boreholes.

Groundwater is the largest and most essential resource of potable water worldwide and millions of people depend on it daily.The quality of groundwater is usually defined regarding its physical, chemical and biological components, which in turn is dependent on the quality of recharge water, atmospheric precipitation, surface-groundwater interaction and geochemical processes (Oki and Oboshenure, 2017). The importance of good quality water to a community cannot be overemphasised as it directly impacts the health, economic development and social prosperity of the populace which utilises it. It also determines the functionality of the ecosystem of the area. Periodic monitoring and evaluation of groundwater quality are thus essential to forestall negative implications associated with the use of contaminated water.

Groundwater's vulnerability to contamination has become a growing concern. Its pollution mainly results from increase in urbanization and industrialization, although it can also be geogenic. These developments are prompted by the generation of solid and liquid wastes, their indiscriminate disposal, and the mismanagement oflandfills and open dump yards. Poisonous chemicals are known to percolate the layers of the earth and terminate in groundwater thereby polluting it and making the inhabitants vulnerable to some health hazards associated with polluted water due to their high dependence on the groundwater. This constitutes public health hazards (Akpabio, 2012).

The United Nations WHO/UNICEF Joint Monitoring Programme has indicated that 2.6 billion people are without improved sanitation and nearly 900 million people lack access to improved source of potable water and this situation is unacceptable (WHO/UNICEF, 2010). To ensure good quality of drinking water, it is important to carry out the qualitative analysis of its microbiological and physicochemical properties. These analysis will help to assess the physical, chemical and biological parameters of the water and its subsequent effects on the health of people.

Several studies on water quality assessment has been carried out in different parts of Nigeria's Federal Capital Territory. These include studies by Ishaya and Abaje (2009) on the assessment of bore well water quality in Gwagwalada town; Ocheriet al., (2014) on groundwater quality in Nigeria's urban areas; Adeeko and Ojo (2015) on underground water distribution system in Gwagwalada Area Council, using resistivity Geo-physical method; Kayodeet al., (2018) on water quality assessment for groundwater in Abuja; and Atikuet al., (2018) on comparative study of the physico-chemical and bacteriological content of groundwater in Jabi. These studies only centered on groundwater quality assessment but did not compare them with pipe-borne water quality, neither did they assess the health implications of the water on the users. This research therefore fills the gap by comparatively assessing the quality of pipe-borne water and groundwater as well as examining the health implications on the people in Gwagwalada town. This was done by analysing the physical, chemical and biological parameters of pipe-borne water and groundwater from selected points in the study area as well as examine the possible

\subsection{Hypothesis}

The null hypothesis posited is as follows:

- Ho: There is no significant difference in the concentration of the analysed parameters between the pipe-borne water and the groundwater samples.

\section{Materials and Methods}

\subsection{Description of the Study Area}

Gwagwalada town is located about $55 \mathrm{~km}$ west of the Federal Capital City (FCC). Its location is also central in the Federal Capital Territory. It lies between latitudes $8^{\circ} 55^{\prime} \mathrm{N}$ and $9^{\circ} 00^{\prime} \mathrm{N}$ and longitude $7^{\circ} 00^{1} \mathrm{E}$ and $7^{\circ} 05^{1} \mathrm{E}$ (FCDA, 1980). It is about the largest existing settlement in the FCT apart from the Federal Capital City. It is a nodal town within the regional and local road networks. It is located on route A2, Kaduna - Lokoja road. The town has a road link with Kuje in the east, and the border town of Izom in the north. Its central location and its relationship with the western half of the FCT surely justify its designation as a growth centre for this region. (Balogun, 2001). Gwagwalada Area Council, in which Gwagwalada town is located is bordered by Kuje Area Council to the East, Abaji Area Council to the West, Kwali area council to the south and Abuja Municipal Area Council to the Northeast and to the North by Suleja Local Government Area of Niger State (Balogun, 2001).

Gwagwalada town is made up of the old town and the new town. The former refers to the older pre-1976 section while the latter results from the impetus of the FCDA, in accordance with its planned role in the spatial development of the FCT. The new town is made up of four districts namely: phases one, two, three and FCDA Staff quarters. It is organized into neighbourhoods and served by local roads unlike the old town (Balogun, 2001). This study, therefore, covers the new town section because it is more organized and can easily be accessible. 


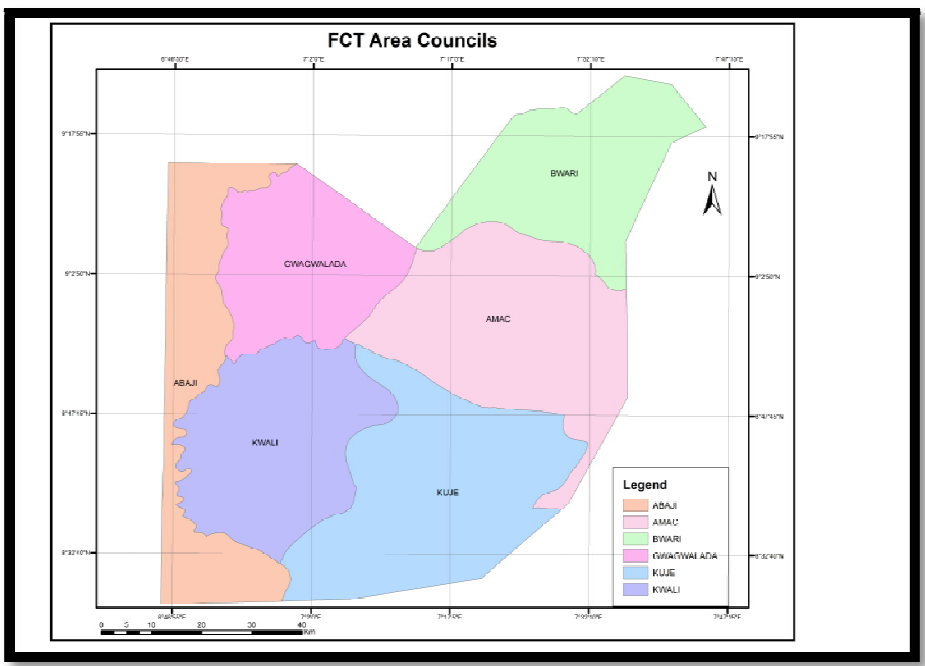

Figure 1: Map of the Federal Capital Territory Showing Gwagwalada Area Council Source: NASRDA (2015)

The climate of Gwagwalada town is the hot, humid tropical type. The highest temperature (between $34.7^{\circ} \mathrm{C}$ and $35.1^{\circ} \mathrm{C}$ ) occurs in the dry season between January and April and the lowest temperature (between $22.8^{\circ} \mathrm{C}$ and $23.3^{\circ} \mathrm{C}$ ) is experienced in august. The rainfall is moderate with annual total ranging approximately between $1,100 \mathrm{~mm}$ and $1,650 \mathrm{~mm}$. Gwagwalada town is drained by River Usuma, a tributary of River Gurara which provides the bulk of water used in the FCT. Hand dug wells and boreholes are found in some compounds but during the dry season when the water table becomes lower, some of these wells dry up (Balogun, 2001).

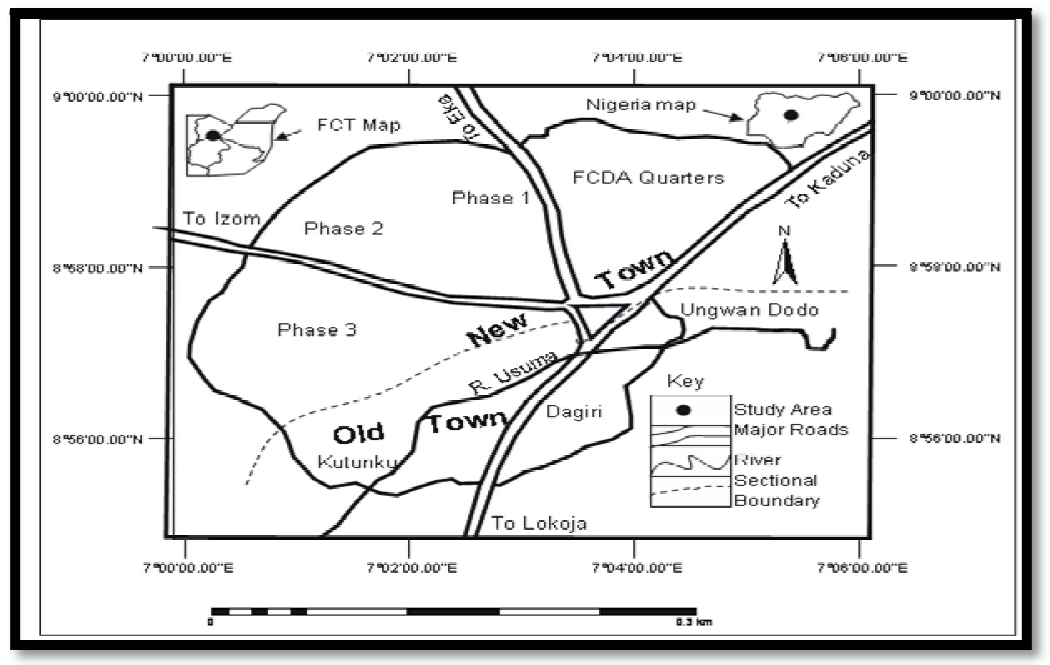

Figure 2: Map of Gwagwalada Town Showing the Planned and Unplanned Areas

Source: Ishaya, 2009

\subsection{Water Samples Collection}

Groundwater samples were collected from selected wells and boreholes in Phase 1, Phase 2, Ungwan Shanu, Ungwan Dodo and Dagiri, comprising the planned and unplanned areas of Gwagwalada town, while pipe-borne water samples were collected from selected points at Phase 1, Phase 2 and Phase 3, comprising only the planned area of the town. The samples were collected using thoroughly cleaned containers which has been pre-rinsed with the water samples to be collected. On-site test of $\mathrm{pH}$ and Electrical conductivity were carried out at each of the sample collection points using Hanna kit (Model H19829), following the standard protocols and methods of American Public Health Association (APHA, 2012). These parameters were analysed on-site because they can easily be affected by changes in the environment.A total of five (5) groundwater samples (wells and boreholes) and three (3) pipe-borne water samples were collected for the study as shown in Table 1. 


\begin{tabular}{|c|c|c|c|c|c|}
\hline Location & Sample Code & Longitude & Latitude & Elevation & No. of Samples \\
\hline Phase 1 & PB1 & $007^{\circ} 04^{\prime} 39^{\prime \prime} \mathrm{E}$ & $008^{\circ} 57^{\prime} 07^{\prime \prime} \mathrm{N}$ & $214 \mathrm{~m}$ & 1 \\
\hline Phase 2 & PB2 & $007^{\circ} 04^{\prime} 18^{\prime \prime} \mathrm{E}$ & $008^{\circ} 56^{\prime} 57^{\prime \prime} \mathrm{N}$ & $200 \mathrm{~m}$ & 1 \\
\hline Phase 3 & PB3 & $007^{\circ} 04^{\prime} 12^{\prime \prime} \mathrm{E}$ & $008^{\circ} 57^{\prime} 37^{\prime \prime} \mathrm{N}$ & $204 \mathrm{~m}$ & 1 \\
\hline Phase 1 & GW1(W) & $007^{\circ} 04^{\prime} 59^{\prime \prime} \mathrm{E}$ & $008^{\circ} 57^{\prime} 28^{\prime \prime} \mathrm{N}$ & $215 \mathrm{~m}$ & 1 \\
\hline Phase 2 & GW2 (B) & $007^{\circ} 04^{\prime} 29^{\prime \prime} \mathrm{E}$ & $008^{\circ} 57^{\prime} 04^{\prime \prime} \mathrm{N}$ & $206 \mathrm{~m}$ & 1 \\
\hline Ungwan Dodo & GW3(W) & $007^{\circ} 05^{\prime} 44^{\prime \prime} \mathrm{E}$ & $008^{\circ} 56^{\prime} 39^{\prime \prime} \mathrm{N}$ & $204 \mathrm{~m}$ & 1 \\
\hline Ungwan Shanu & GW4(W) & $007^{\circ} 04^{\prime} 08^{\prime \prime} \mathrm{E}$ & $008^{\circ} 56^{\prime} 51^{\prime \prime} \mathrm{N}$ & $192 \mathrm{~m}$ & 1 \\
\hline Dagiri & GW5(B) & $007^{\circ} 05^{\prime} 15^{\prime \prime} \mathrm{E}$ & $008^{\circ} 55^{\prime} 59^{\prime \prime} \mathrm{N}$ & $189 \mathrm{~m}$ & 1 \\
\hline
\end{tabular}

Table 1: Sampling Frame

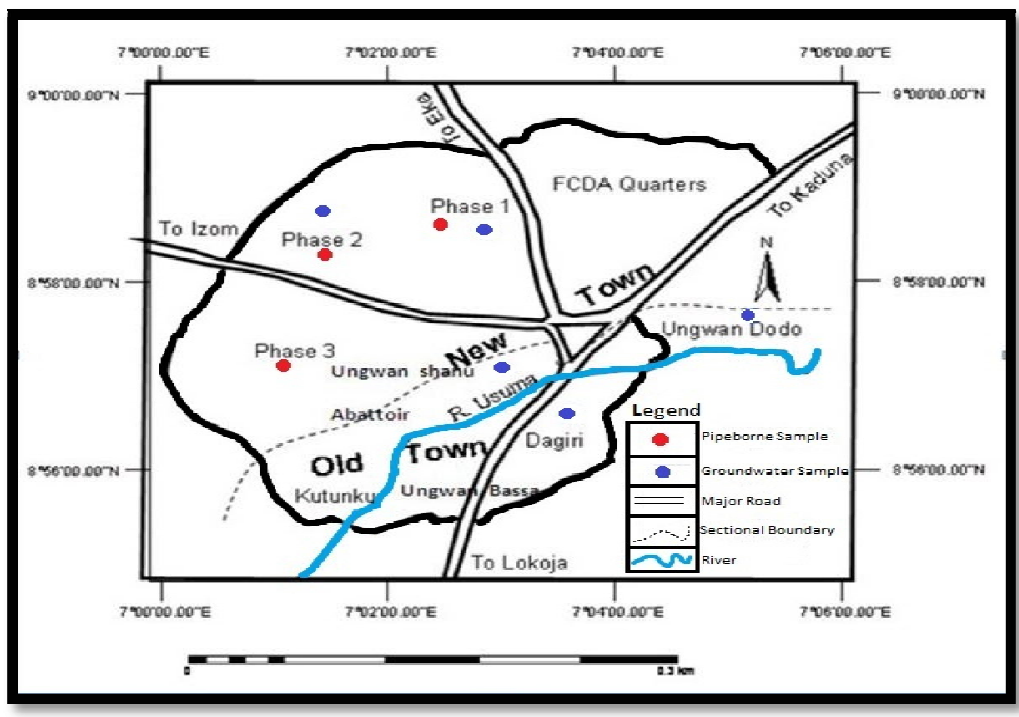

Figure 3: Map of Gwagwalada Town Showing Points of Sample Collection

\subsection{Laboratory Analysis}

After collection, the samples were sealed, labeled and transported under the prescribed standard conditions to the laboratory (Zabson Laboratory Services Ltd, Asokoro, Abuja) where they were analysed for selected physical, chemical and biological parameters. Prescribed precautions (Goudarzi, 2015) were taken in the handling and transportation of the samples. Parameters analysed in the laboratory include Dissolved oxygen (D0), Total Hardness, Total Chlorine, Chloride, Nitrate, Ammonia, Sulphate, Phosphate, Iron, Lead, Zinc, Copper, Cadmium, Manganese, Aluminium and Total coliform count.

\subsection{Methods of Data Analysis}

The data obtained from the field and laboratory analysis of the water samples were analyzed empirically, presented in tables and graph and discussed accordingly. The results of the laboratory analysis of the water samples were compared with the World Health Organisation (WHO) and Federal Ministry of Environment (FME) drinking water standards. The stated hypothesis was statistically tested using the student t-test, which is given by the expression:

$$
\mathrm{t}=\frac{\bar{x}_{1-\bar{x}_{2}}}{\sqrt{\left(\sigma_{1}^{2} / N_{1}\right)+\sigma_{2}^{2} / N_{2}}}
$$

Where:

$\overline{\mathcal{X}}_{1}=$ mean variable one (groundwater samples); $\overline{\mathcal{X}}_{2}=$ mean variable two (pipe-borne water samples); $\sigma_{1}^{2}=$ the square of the standard deviation of variable one; $\sigma_{2}^{2}=$ the square of the standard deviation of variable two; $N_{1}=$ total number of values in variable one; $N_{2}$ total number of values in variable two. 
3. Results and Discussion

The results of the laboratory analysis of the water samples are as presented in Table 2 and Figures 4 to 21 .

\begin{tabular}{|c|c|c|c|c|c|c|c|c|c|c|}
\hline $\begin{array}{c}\text { Parameters } \\
\text { Mg/L }\end{array}$ & PB1 & PB2 & PB3 & GW1(W) & GW2(B) & GW3(W) & GW4(W) & GW5(B) & FME & $\begin{array}{c}\text { WHO } \\
\text { Standard }\end{array}$ \\
\hline $\mathrm{pH}$ & 8 & 7 & 6.5 & 6 & 8 & 6.5 & 6.5 & 7 & 8.5 & 8.5 \\
\hline $\begin{array}{c}\text { Conductivity( } \mu \mathrm{s} \\
\mathrm{cm} / \mathrm{l})\end{array}$ & 51 & 48 & 46 & 84 & 43 & 108 & 111 & 109 & 1000 & 1000 \\
\hline $\begin{array}{c}\text { Dissolved } \\
\text { Oxygen }\end{array}$ & 9.3 & 9.22 & 9.22 & 34 & 11 & 37 & 28 & 9 & NA & NA \\
\hline $\begin{array}{c}\text { Total } \\
\text { Hardness }(\mathrm{Mg} / \mathrm{L})\end{array}$ & 51.36 & 34.24 & 37.24 & 68.48 & 44.4 & 46.06 & 54.48 & 51.36 & 150 & 300 \\
\hline Sulphate & 37.9 & 50 & 44.3 & 8.5 & 14.2 & 100 & 39.8 & 23.2 & 100 & 250 \\
\hline Phosphate & 0.2 & 0.4 & 0.13 & 0.8 & 0.4 & 1.3 & 0.6 & 0.5 & 5 & N.A \\
\hline $\begin{array}{c}\text { Total } \\
\text { Chlorine }(\mathrm{Mg} / \mathrm{L}) \\
\end{array}$ & 1.23 & 1.26 & 0.24 & 0.03 & 0.1 & 0.08 & 0.05 & 0.1 & 4 & 5 \\
\hline Chloride (Mg/L) & 4.797 & 2.055 & 1.695 & 34 & 47 & 63 & 32 & 23 & 250 & 250 \\
\hline Nitrate & 8 & 11 & 8 & 10 & 5.4 & 12.45 & 19.5 & 15.3 & 20 & 50 \\
\hline Ammonium & 0.04 & 0.3 & 0.1 & 0.05 & 0.04 & 0.05 & 0.05 & 0.04 & 10 & 0.5 \\
\hline Cadmium & 0.002 & 0.001 & 0.002 & 0.021 & 0.084 & 0.073 & 0.027 & 0.021 & 0.003 & 0.003 \\
\hline Copper & 0.1 & 1 & 1.2 & 1.6 & 0.2 & 1.1 & 1.393 & 1.7 & NA & 2 \\
\hline Manganese & 0.2 & 0.3 & 0.4 & 0.5 & 0.3 & 0.5 & 0.44 & 0.37 & 0.2 & 0.4 \\
\hline Aluminium & 0.2 & 0.09 & 0.1 & 0.6 & 0.5 & 11 & 24 & 18 & 0.2 & 0.2 \\
\hline Iron Total & 0.2 & 0.2 & 0.2 & 0.8 & 0.3 & 0.7 & 1.1 & 2.6 & 0.3 & 0.3 \\
\hline Zinc & 0.5 & 0.4 & 0.6 & 4.1 & 6.4 & 7.1 & 4.79 & 3.9 & 3 & 5 \\
\hline Lead & 0.009 & 0.02 & 0.02 & 0.004 & 0.005 & 0.02 & 0.02 & 0.03 & 0.01 & 0.01 \\
\hline $\begin{array}{c}\text { Faecal Coliform } \\
\text { Count }\end{array}$ & 100 & 400 & 200 & 500 & 1210 & 1000 & 1300 & 900 & 0 & 0 \\
\hline
\end{tabular}

Table 2: Concentration of the Physical, Chemical and Biological Parameters of Pipe-Borne Water and Groundwater Samples WHO, (2003, 2008, 2017); FME, (1991); Field work, 2019 NA -Not Available

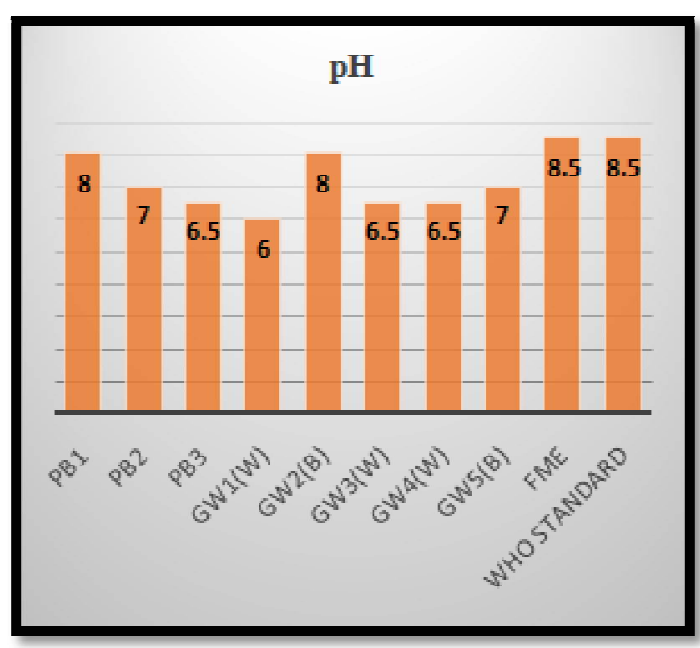

Figure 4: $p H$ of the Water Samples 


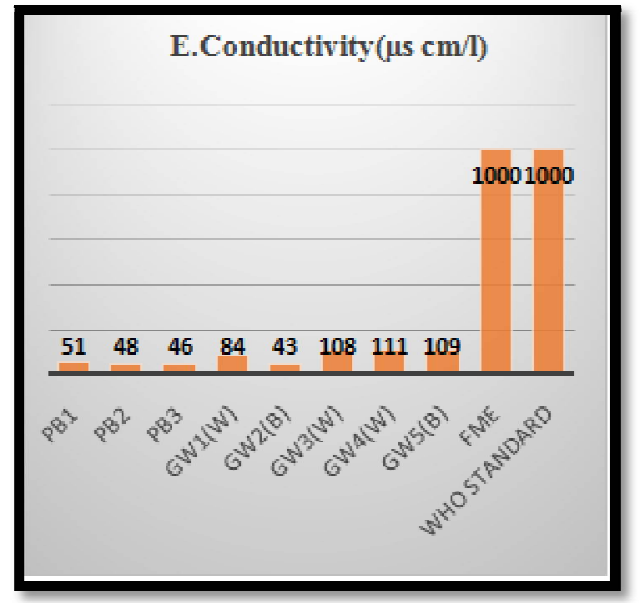

Figure 5: E. Conductivity of the Water Samples

- $\mathbf{p H}$ : The $\mathrm{pH}$ of the pipe-borne (PB) water samples ranged from 6.5 to 8 while those of the groundwater (GW) samples ranged from 6 to 8. Across the groundwater samples, the well water samples (GW(W)) have lower $\mathrm{pH}$ than the borehole (GW(B)) water samples, indicating that they (well water) are slightly more acidic. The $\mathrm{pH}$ values of all the water samples fall within World Health Organization (WHO) and Federal Ministry of Environment (FME) Standard of 6.5-8.5 except for GW1 (6) which is lower than the standards. Waters with pH lower than 4 have a sour taste and above 8.5 an alkaline bitter taste. The $\mathrm{pH}$ of water can indirectly affect health. It places adults at risk for health problems such as cancer, stroke, kidney disease, memory problems and high blood pressure. Exposure to extreme $\mathrm{pH}$ values results in irritation to the eyes, skin, and mucous membranes (WHO, 2003a; Makwe and Chup, 2013a; Makwe, 2020).

\subsection{Electrical Conductivity}

The EC of the pipe-borne water samples ranged from $46-51 \mu \mathrm{s} \mathrm{cm} / 1$ while those of the groundwater samples ranged from $43-111 \mu \mathrm{s} \mathrm{cm} / \mathrm{l}$. The groundwater samples have higher EC than the pipe-borne water samples. The EC of all the water samples fall within WHO (2003a) and FME (1991) Standard of $1000 \mu \mathrm{scm} / \mathrm{l}$.

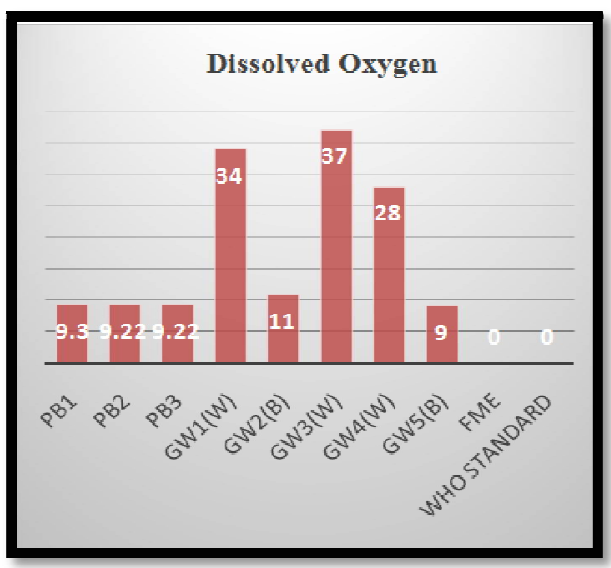

Figure 6: D.O.of the Water Samples

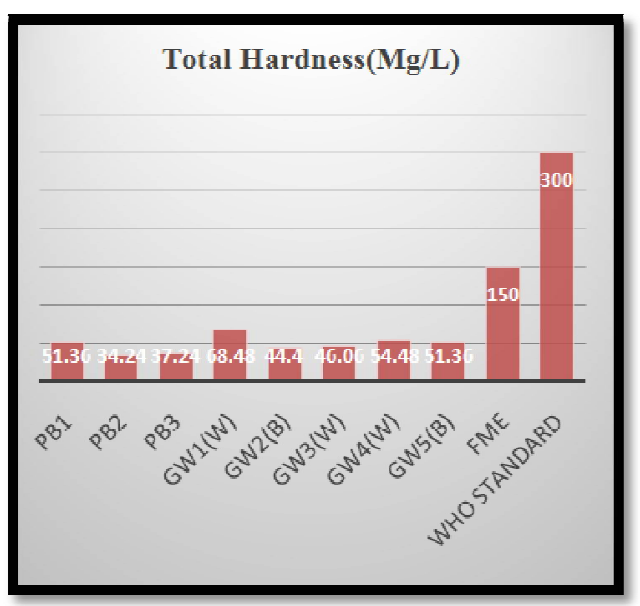

Figure 7: Total Hardness of the Water Samples 


\subsection{Dissolved Oxygen}

Dissolved oxygen refers to the level of free, non-compound oxygen present in water (Horne and Goldman, 1994; Makwe and Chup, 2013b). The dissolved oxygen content of water is influenced by the source, raw water temperature, treatment and chemical or biological processes taking place in the distribution system. The pipe-borne water samples have DO which ranged from $9.22-9.3 \mathrm{mg} / \mathrm{l}$ while the groundwater samples generally ranged from $9-37 \mathrm{mg} / \mathrm{l}$, with the borehole water having less DO $(9-11 \mathrm{mg} / \mathrm{l})$ than the well water $(28-37 \mathrm{mg} / \mathrm{l})$. The low DO in the borehole water is most probably due to the anaerobic conditions at the groundwater level. Healthy water should generally have dissolved oxygen concentration of above $6.5-8 \mathrm{mg} / \mathrm{l}$ (Horne and Goldman, 1994). There is no health-based guideline value recommended for DO in drinking water, however, low DO can encourage microbial reduction of nitrate to nitrite and sulphate to sulphide, giving rise to anaerobic condition, putrefaction and development of foul odour while very high levels of dissolved DO may exacerbate corrosion of metal pipes (WHO, 2012; Makwe and Chup, 2013b).

\subsection{Total Hardness}

The total hardness ( $\mathrm{Ca}$ and $\mathrm{Mg}$ ) for all the collected water samples ranged from 34.24-68.48mg/l and are within the WHO (2012) and FME (1991) standard of $100-300 \mathrm{mg} / \mathrm{l}$ and $150 \mathrm{mg} / \mathrm{l}$ respectively. Public acceptability of the degree of hardness of water may vary considerably from one community to another. Depending on the interaction of other factors, such as $\mathrm{pH}$ and alkalinity, water with a hardness above approximately $200 \mathrm{mg} / \mathrm{l}$ may cause scale deposition in the treatment works, distribution system and pipework and tanks within buildings (WHO, 2012).

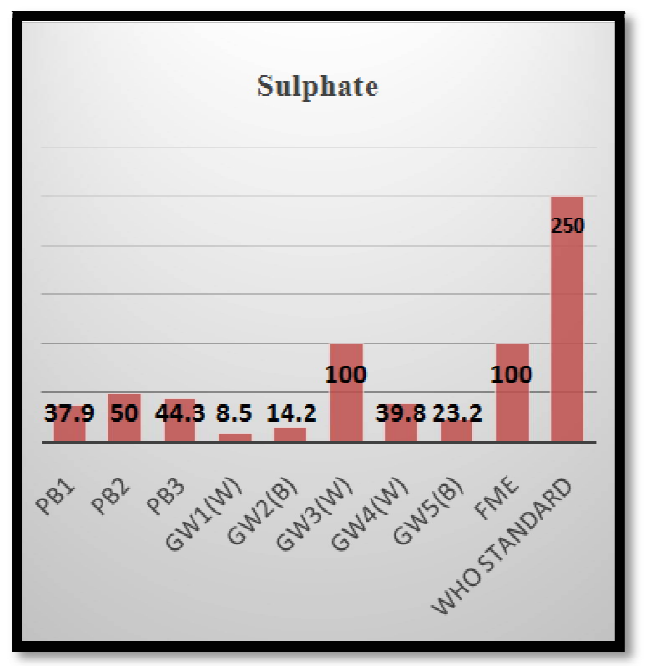

Figure 8: Sulphate Concentration

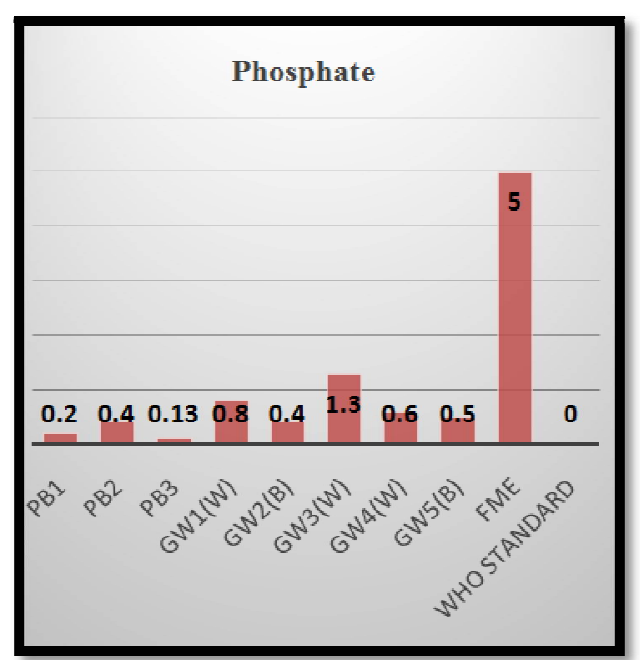

Figure 9: Phosphate Concentration

\subsubsection{Sulphate}

The concentration of sulphate in the water samples across the sampling locations ranged from $8.5-100 \mathrm{mg} / \mathrm{l}$ with the values generally higher in the pipe-borne water samples, except for GW3(W) (an open well), which had the highest concentration of $100 \mathrm{mg} / \mathrm{l}$. All the water samples have sulphate concentration that falls withinthe WHO (2008) and FME (1991)standard of $250 \mathrm{mg} / \mathrm{l}$ and $100 \mathrm{mg} / \mathrm{l}$ respectively.The presence of sulphate in drinking-water can cause noticeable taste, and very high levels might cause a laxative effect in unaccustomed consumers (WHO, 2004b) 


\subsubsection{Phosphate}

The concentration of phosphate in the water samples ranged from 0.13 to $1.3 \mathrm{mg} / \mathrm{l}$, with the groundwater samples having higher concentrations than the pipe-borne. Their concentrations are however within the FME (1991) maximum value of $5 \mathrm{mg} / \mathrm{l}$. There are no WHO guideline values provided for phosphate in drinking water.

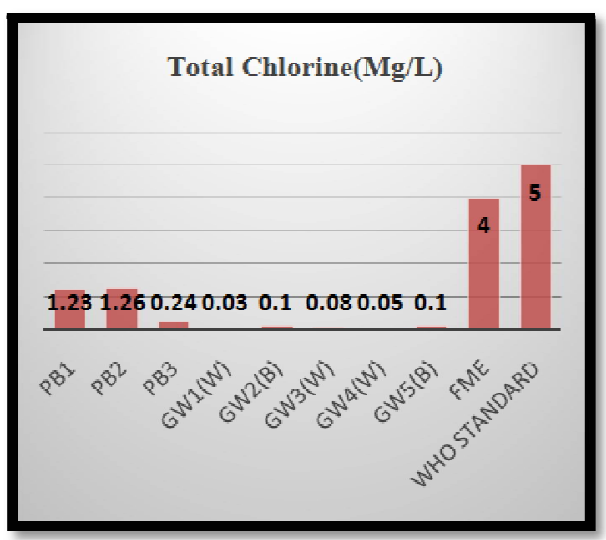

Figure 10: T. Chlorine Concentration

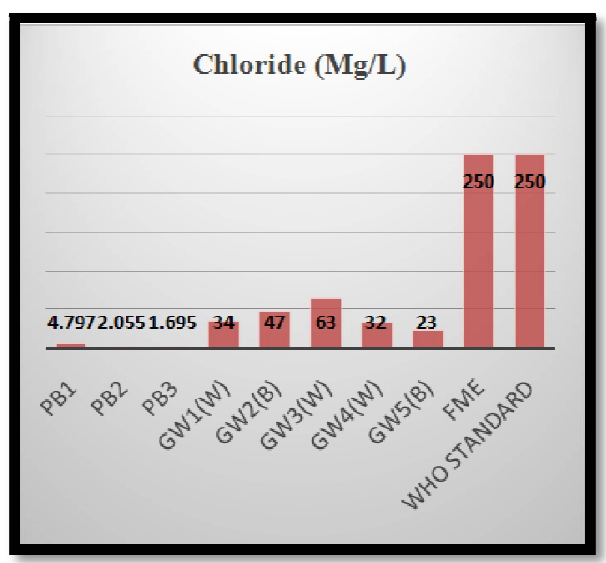

Figure 11: Chloride Concentration

\subsubsection{Total Chlorine}

T. chlorine concentration in all the water samples ranged from $0.03-1.26 \mathrm{mg} / \mathrm{l}$. The pipe-borne water samples have higher concentration $(0.24-1.26 \mathrm{mg} / \mathrm{l})$ than the groundwater samples $(0.03-0.1 \mathrm{mg} / \mathrm{l})$. The elevated concentration in the pipe-borne water samples are due to the treatment of the water with chlorine before its distribution to the consumers. They are however, within the WHO (2012) and FME (1991) guideline values of 4mg/l and 5mg/l respectively. Human exposure to high chlorine concentration in drinking water results in airway irritation, wheezing, difficulty in breathing, sneezing, increased dryness in throat and cough (WHO, 2012).

\subsubsection{Chloride}

Concentration in the water samples ranged from $1.695-63 \mathrm{mg} / \mathrm{l}$, with the groundwater samples having higher concentrations $(23-63 \mathrm{mg} / \mathrm{l})$ due to the different chloride salts that may occur in the underlying rocks. The chloride concentration are still within the FME (1991) and WHO (2012) standard. High concentrations of chloride give a salty taste to water.

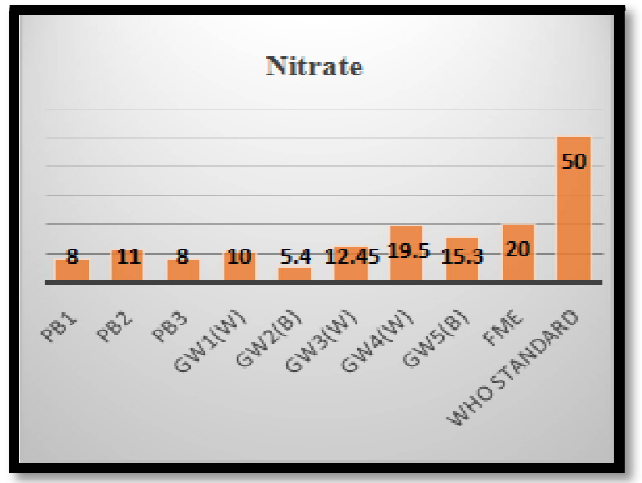

Figure 12: Nitrate Concentration 


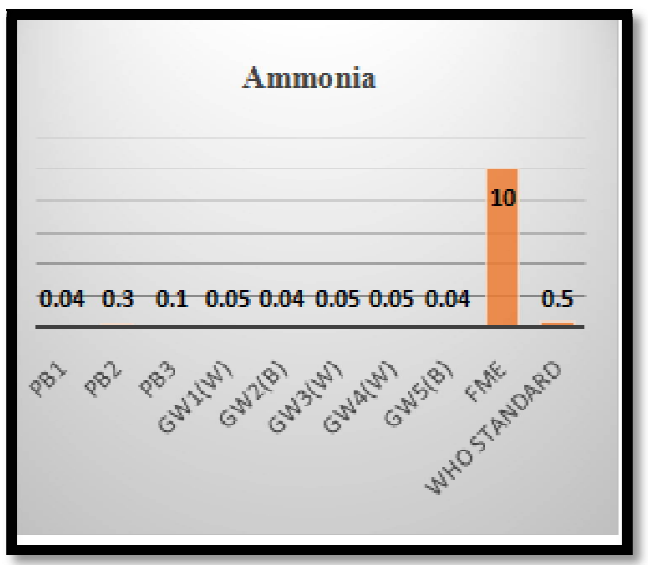

Figure 13: Ammonia Concentration

\subsubsection{Nitrate}

The higher concentration of nitrate in the groundwater samples $(5.4-19.5 \mathrm{mg} / \mathrm{l})$ than in the pipe-borne water samples $(8-11 \mathrm{mg} / \mathrm{l})$ is an indication that human activities on the surface can have adverse effects on groundwater through the infiltration of materials from the soils into the groundwater store.The concentration of nitrate in all the water samples fall within the WHO standard of 50mg/l and Federal Ministry of Environment Standard of 20mg/l.

\subsubsection{Ammonia}

The threshold odour concentration of ammonia at alkaline $\mathrm{pH}$ is approximately $1.5 \mathrm{mg} / \mathrm{l}$, and a taste threshold of $35 \mathrm{mg} / \mathrm{l}$ has been proposed for the ammonia. Ammonia is not of direct relevance to health at these levels. The value of Ammonia of groundwater sample ranged from 0.04 to $0.05 \mathrm{mg} / \mathrm{l}$ while those of pipe-borne water ranges from 0.04$0.1 \mathrm{mg} / \mathrm{l}$. These values were within the recommended standard values of 10mg/l (FME, 1991).

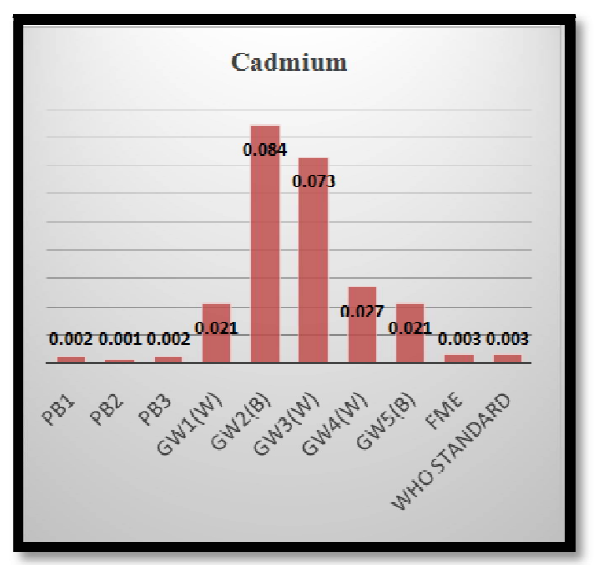

Figure 14: Cadmium Concentration

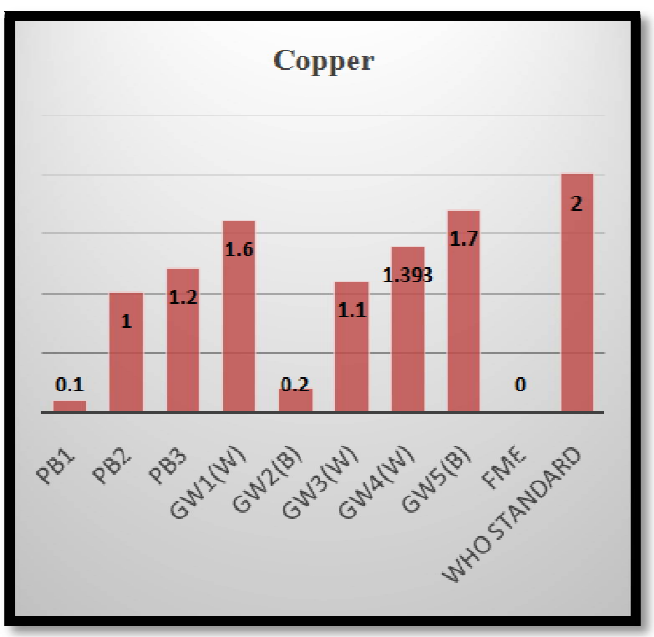

Figure 15: Copper Concentration 


\subsubsection{Cadmium}

The pipe-borne water had cadmium concentration that ranged from $0.001-0.002 \mathrm{mg} / \mathrm{l}$ and are within the WHO (2012) and FME (1991) standards. The groundwater samples however had elevated levels of cadmium concentrations that ranged from $0.021-0.084 \mathrm{mg} / \mathrm{l}$. These values are higher than the recommended standard values of $0.003 \mathrm{mg} / \mathrm{l}$ (WHO, 2012; FME, 1991). The higher concentration of cadmium in the groundwater samples are most likely due to the nature of the underlying rocks, which may be laden with the metal. It could also be due to the anthropogenic activities around there which has led to the groundwater pollution. Elevated concentrations of $\mathrm{Cd}$ can cause nausea, vomiting, salivation and renal failure as well as kidney, liver and blood damages (Soylak et. al., 2002). Singh and Mosle (2003) suggested that high concentrations of Cadmium may even cause mutations.

\subsubsection{Copper}

Concentration in all the water samples ranged from $0.1-1.7 \mathrm{mg} / \mathrm{l}$. These concentrations are within the recommended standard value of $2 \mathrm{mg} / \mathrm{l}$ (WHO, 2012). The FME does not have a guideline value for copper in drinking water. The pipe-borne water sample at point PB1 had the least copper concentration while the groundwater sample at point GW2 (borehole) had the highest copper concentration. Copper in pipe-borne water supply usually arises from the corrosive action of water on copper pipes. The concentrations can vary significantly with the period of time the water has been standing in contact with the pipes.

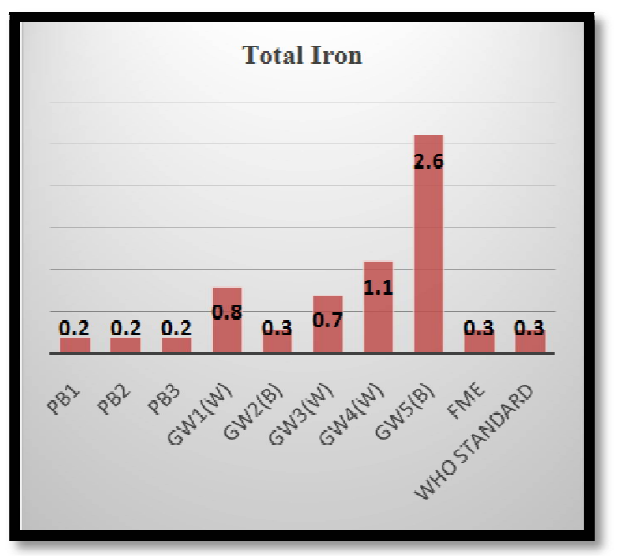

Figure 16: T. Iron Concentration

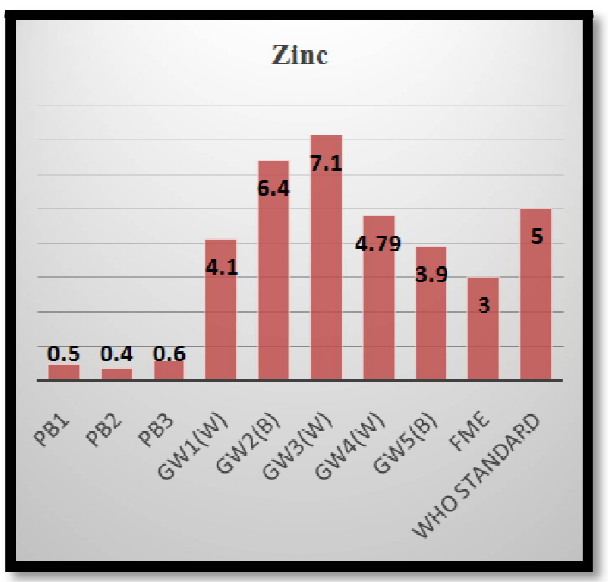

Figure 17: Zinc Concentration

\subsubsection{Iron}

All the pipe-borne water samples had iron concentrations $(0.2 \mathrm{mg} / \mathrm{l})$ which are within the $0.3 \mathrm{mg} / \mathrm{l}$ WHO (2012) and FME (1991) standard. The groundwater samples however, had iron concentrations that ranged from 0.3-2.6mg/l. These concentrations are higher than the recommended standard value of 0.3mg/l (WHO, 2012; FME 1991). Although low levels of iron in drinking water cannot do much harm, it is however considered a contaminant because it also contain bacteria that feed off it. High iron concentration in drinking water can lead to iron overload in humans and this can cause diabetes, hemochromatosis, stomach problems, nausea and vomiting. It can also damage the liver, pancreas and heart (WHO, 2012). The levels of iron in groundwater can be due to large amounts of iron deposits within the rocks. It can also be increased by the dissolution of ferrous borehole and hand pump components (Lenntech, 2009; Oyem et al., 2015)

\subsubsection{Zinc}

Concentration (0.4-0.6mg/l) in the pipe-borne water are within the 5mg/l WHO (2012) standard and the 3mg/l FME (1991) standard. The concentration of zinc in the groundwater samples (3.9-7.1 mg/l) are however higher than those of the pipe-borne water samples and are also higher than the recommended standard values of $3 \mathrm{mg} / \mathrm{l}$ and $5 \mathrm{mg} / \mathrm{l}$ for FME 
and WHO respectively. Elevated levels of zinc in groundwater is due to the available deposits within the earth and also due to the use of galvanized plumbing materials for boreholes (Oyem et al., 2015). Zinc is an essential nutrient for body growth and development, however, drinking water containing high levels of zinc can lead to stomach cramps, nausea and vomiting (ATSDR, 1994).

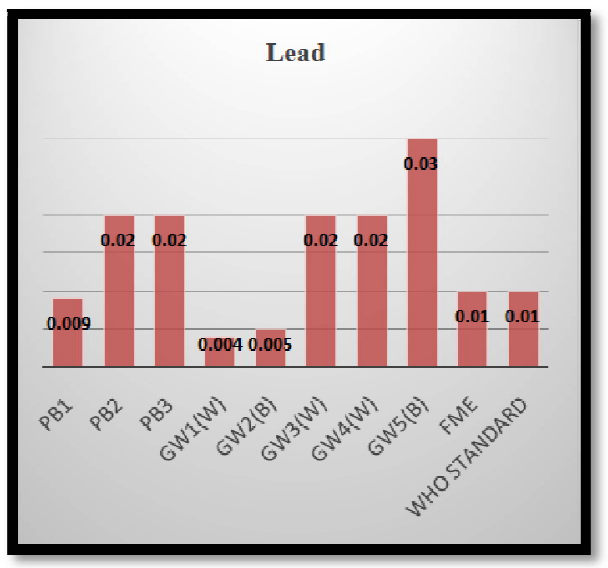

Figure 18: Lead Concentration

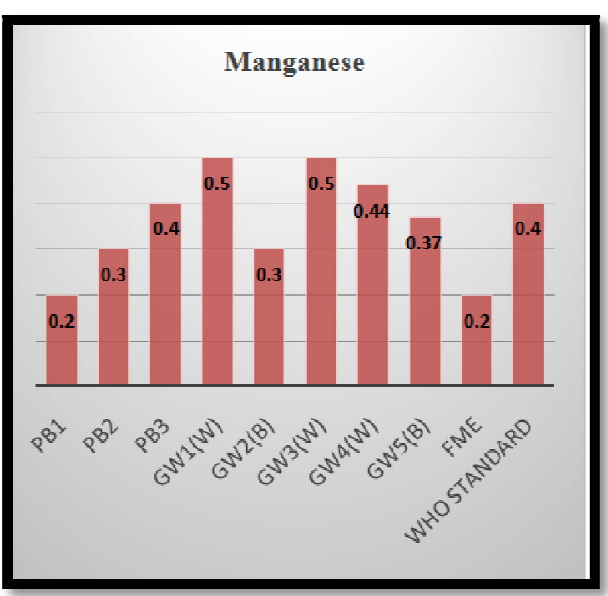

Figure 19: Manganese Concentration

\subsubsection{Lead}

Lead concentration in the pipe-borne water and groundwater are higher than the guideline values of $0.01 \mathrm{mg} / \mathrm{l}$ (FME, 1991; WHO, 2012) except for those from points PB1, GW1 and GW2 whose concentrations were 0.009mg/l, $0.004 \mathrm{mg} / \mathrm{l}$ and $0.005 \mathrm{mg} / \mathrm{l}$ respectively. The elevated levels of lead concentration are partly due to the existence of lead deposits in the area and partly due to the gradual dissolution of the lead pipes which are used for water distribution. Kidney and liver are considered potential targets of $\mathrm{Pb}$ toxicity before storage in bones. Depending on the level of exposure, $\mathrm{Pb}$ has potential to cause decreased hemoglobin synthesis, impairment of neurobehavioral and psychological functions, peripheral neuropathy, indirect effect on heart, renal tubular damage and reproductive problems (Levallois et al., 2018; WHO, 2019). Children are particularly susceptible to $\mathrm{Pb}$ exposure due to high gastrointestinal uptake, and the permeable blood brain barrier leading to neurotoxin effects even at low level of exposure (Merem et al., 2017, Makwe, 2020).

\subsubsection{Manganese}

The concentration of manganese in the water samples are within the WHO standard value of $0.4 \mathrm{mg} / \mathrm{l}$ except for the samples from points GW1, GW3 and GW4, whose concentrations were $0.5 \mathrm{mg} / \mathrm{l}, 0.5 \mathrm{mg} / \mathrm{l}$ and $0.44 \mathrm{mg} / \mathrm{l}$ respectively. They are however higher than the FME guideline value of $0.2 \mathrm{mg} / \mathrm{l}$. Elevated levels of manganese in drinking water has adverse health effects. High exposure to manganese has been associated with toxicity in the nervous system, producing a syndrome that resembles Parkinsonism known as Manganese. Effects of $\mathrm{Mn}$ exposure also include decrease in systolic blood pressure, change in erythropoiesis and granulocyte formation (WHO, 2003b; Sengupta, 2013). 


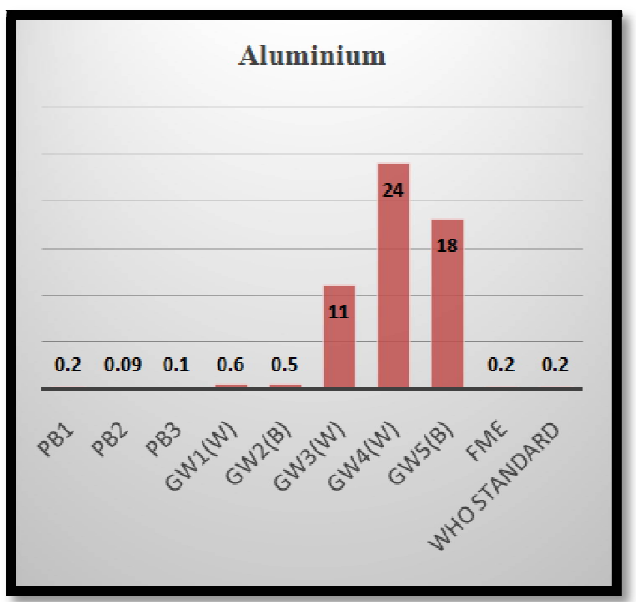

Figure 20: Aluminium Concentration

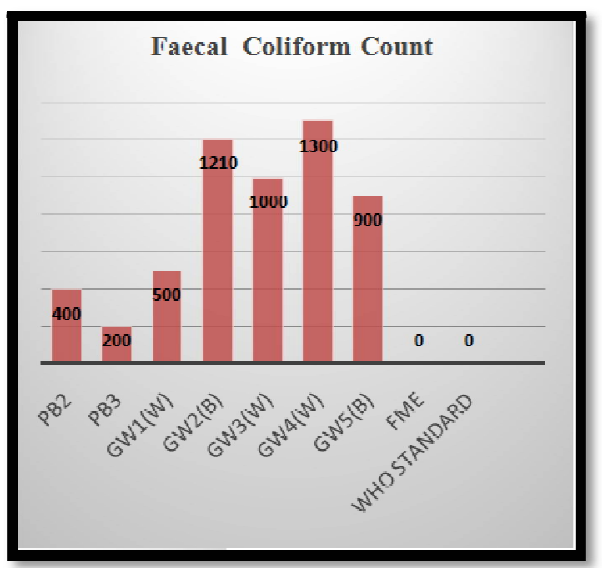

Figure 21: Faecal Coliform Count

\subsubsection{Aluminium}

The pipe-borne water samples had aluminium concentration which ranged from $0.09-0.2 \mathrm{mg} / \mathrm{l}$. These concentrations are within the guideline standard of 0.2 (FME, 1991; WHO, 2008). On the other hand, the groundwater samples had aluminium concentrations that are higher than the standards. These elevated concentration is due to the abundant deposits of aluminium in the area. While there is no evidence to suggest that ingestion of water that naturally contain traces of aluminium is harmful, several investigators have recently reported cases in which short-term exposures to high aluminium levels in drinking water resulted in clinical diagnoses of dementia (Willhite et al., 2014; Klotz et al., 2017).

\subsubsection{Faecal Coliform Count}

The faecal coliform count in the water samples ranged from $200-1300 \mathrm{cfu} / 100 \mathrm{ml}$. These are higher than the recommended guideline value of $0 \mathrm{cfu} / 100 \mathrm{ml}$ (FME, 1991; WHO, 2012). The microbial contamination of water is often of faecal nature relating to humans through open defecation, indiscriminate disposal of wastes, overflow and non-channeled sewage disposal, and so many others. Some of these infiltrate into the soil and pollutes the groundwater. In areas where pipes for pipe-borne water distribution are broken or vandalized, they can also pollute the water. Infectious diseases caused by pathogenic bacteria, viruses and parasites (e.g. protozoa and helminthes) are the most common and widespread health risks associated with drinking water. Some of these pathogens that are known to be transmitted through contaminated drinking water lead to severe and sometimes life threatening diseases like typhoid, cholera, infectious hepatitis (WHO, 2008).

The results therefore showed that the values (concentration) of parameters such as $\mathrm{pH}$, EC, Total hardness, sulphate, phosphate, ammonia and copper for both the pipe-borne water and groundwater samples were within the WHO and FME standards, while those of manganese and faecal coliform count are higher than the standards across all the samples. The concentration of parameters such as chloride, nitrate, cadmium, iron, Zinc and aluminium, in the pipe-borne water are within the standards. They are however, higher than the standard in the groundwater samples. Total chlorine has higher concentration in the pipe-borne water samples while Lead has elevated concentration in two of the pipe-borne water samples (PB2 and PB3) and three of the groundwater samples (GW3, GW4 and GW5). There is no guideline value for dissolved oxygen, however, the pipe-borne water has less DO than the groundwater samples. The higher concentration of the tested parameters in the groundwater samples are partly due to human activities, which leads to the generation and indiscriminate disposal of waste that infiltrate and pollute the groundwater. It is also partly due to the availability of mineral deposits within the earth where the groundwater samples are taken from. The high concentration of chlorine in the pipe-borne water samples are due to the use of chlorine for water treatment which results in the availability of 
residual chlorine in the water. Whereas the high concentration of lead is due to the gradual dissolution of the lead pipes which were used to channel and distribute the water. The results of this study corroborates that which was carried out by Akin-Osanaiye et al. (2018) in their comparative analysis of pipe borne water and other sources of water in Gwagwalada Area Council.

For most of the parameters therefore, their concentrations are higher in the groundwater samples than in the pipe-borne water samples, except for lead, manganese and faecal coliform, where the concentrations are higher than the standard in both the pipe-borne water and groundwater samples. This is an indication that the groundwater samples are more polluted than the pipe-borne water samples

\subsection{Test of Hypothesis}

The earlier stated hypothesis (Ho) that there is no significant difference in the concentration of the analysed parameters between the pipe-borne water and the groundwater samples was tested using the student t-test as shown in Tables 3and 4 .

\begin{tabular}{|c|c|c|c|c|}
\hline & & N & Correlation & Sig. \\
\hline Pair 1 & PB\& GW & 18 & .977 & .000 \\
\hline \multicolumn{5}{|c}{ Table 3: Paired Samples Correlations }
\end{tabular}

\begin{tabular}{|c|c|c|c|c|c|c|c|c|}
\hline & \multicolumn{5}{|c|}{ Paired Differences } & \multirow[t]{2}{*}{$\mathbf{T}$} & \multirow[t]{2}{*}{ df } & \multirow{2}{*}{$\begin{array}{c}\text { Sig. } \\
\text { (2-tailed) }\end{array}$} \\
\hline & \multirow[t]{2}{*}{ Mean } & \multirow[t]{2}{*}{$\begin{array}{c}\text { Std. } \\
\text { Deviation }\end{array}$} & \multirow[t]{2}{*}{$\begin{array}{l}\text { Std. Error } \\
\text { Mean }\end{array}$} & \multicolumn{2}{|c|}{$\begin{array}{c}95 \% \text { Confidence Interval of } \\
\text { the difference }\end{array}$} & & & \\
\hline \multirow{2}{*}{$\begin{array}{c}\text { Pair } 1 \\
\text { PB - } \\
\text { GW }\end{array}$} & & & & Lower & Upper & \multirow[t]{2}{*}{-1.166} & \multirow[t]{2}{*}{17} & \multirow[t]{2}{*}{.260} \\
\hline & $\begin{array}{c}- \\
4.8198144 \mathrm{E} 1\end{array}$ & 175.3027572 & 41.3192561 & $\begin{array}{c}- \\
135.3741547\end{array}$ & 38.9778658 & & & \\
\hline
\end{tabular}

Table 4: Paired Sample Test

The t-test result shows that the calculated value $(0.260)$ is greater than the critical value $(-1.166)$ at 0.05 significant level. The null hypothesis is therefore rejected and is concluded that there is significant difference in the concentration of the analysed parameters between the pipe-borne (PB) water and the groundwater (GW) samples.

\subsection{Possible Health Implications}

With the elevated concentrations of $\mathrm{Cd}, \mathrm{Fe}, \mathrm{Zn}, \mathrm{Pb}, \mathrm{Mn}, \mathrm{Al}$ and Faecal coliforms, which has resulted in the pollution of the water, especially the groundwater, residents who consume the water are at risk of some water borne bacterial, viral and fungal health complications that could arise from the continuous consumption. Health risk associated with polluted waterincludes different diseases such as respiratory disease, cancer,diarrheal disease, neurological disorder and cardiovasculardisease (Ullah et al., 2014). Others include includestomach upset, nausea, vomiting, typhoid, cholera, hepatitis, liver, kidney and heart failures, psychological and neurological problems and dementia among others (Makwe, 2020).Many waterborne infectious diseases are linked withfaecal pollution of water sources and results in faecal-oral routeof infection (Nel and Markotter, 2009). Nitrogenous chemicals are responsible for cancerand blue baby syndrome (Krishnan and Indu, 2006). Contaminated water has large negativeeffects in those women who are exposed to chemicals duringpregnancy; it leads to the increased rate of low birth weight as aresult foetal health is affected (Currie et al., 2013).

\section{Conclusion and Recommendations}

The study showed that the water in the study area are polluted, with higher concentration of $\mathrm{Cd}, \mathrm{Fe}, \mathrm{Zn}, \mathrm{Pb}, \mathrm{Mn}, \mathrm{Al}$ and Faecal coliforms in the groundwater than in the pipe-borne water. It also showed that there is a significant difference in the concentration of the analysed parameters between the pipe-borne water and the groundwater; and that the consumers are at risk of water borne diseases due to the continuous consumption of the well and borehole water from the study area. It therefore recommends that the water be treated before consumption; wells and boreholes should be located away from open waste dump sites and from areas where human activities pollute the water sources. There should be continuous monitoring by the FCT Water Board authority and other relevant agencies in other to locate, repair and maintain rusted, broken and vandalized pipes. Simple water quality test kits and purifiers (e.g. Water guard) should be made available and affordable to the people in the study area. This will go a long way to reduce the incidences of water borne diseases.

\section{Acknowledgements}

The pipe-borne water and groundwater samples were collected by Olanrewaju Odunayo and Adeleke Taiwo Samuel respectively. Thanks to the management and staff of Zabson Laboratory Services Ltd for the analysis of the water samples.

\section{References}

i. Adeeko T.O. and Ojo E.O. (2015). Underground Water Distribution System in Gwagwalada Area Council Abuja, Nigeria, using Resistivity Geophysical Method. International Journal of Scientific Research in Agricultural Sciences, 2(4), 097-104. 
ii. Afolabi, T.A.; Ogbuneke, C.C.; Ogunkunle, O.A. and Bamiro, F.O. (2012) Comparative Assessment of the Potable Quality of Water from Industrial, Urban and Rural Parts of Lagos, Nigeria. Ife Journal of Science Volume 14 No 2 pp 221-232

iii. Agency for Toxic Substance and Disease Registry ATSDR. (1994). Toxicological profile for zinc. US Department of Health and Human Services, Public Health Services. 205, 88-608.

iv. Akin-Osanaiye, B.C., Mohammed, S.E., Echoki, J. (2018) Comparative Analysis of Pipe borne Water and other Sources of Water in Gwagwalada Area Council, Federal Capital Territory, Abuja, Nigeria. Journal of Biology and Genetic Research Vol. 4 No. 12018

v. Akpabio, E.M. (2012). Water Meanings, Sanitation Practices and Hygiene Behaviours in the Cultural Mirror: A Perspective from Nigeria. Journal of Water Sanitation and Hygiene for Development 02(3): 168-181

vi. American Public Health Association (APHA) (1995) Standard Methods for the Examination of Water and Wastewater. 19th Edition, American Public Health Association Inc., New York.

vii. Atiku, S.; Ogbaga, C.C.; Alonge, O.O. and Nwagbara, O.F. (2018) Comparative Study of Physico-Chemical and Bacteriological Qualities of some Drinking Water Sources in Abuja. Global Journal of Pure and Applied Sciences Vol 24 No 1 www.iiardpub.org

viii. Balogun, O. (2001). The Federal Capital Territory of Nigeria: A Geography of its Development; Ibadan University Press. 35-37.

ix. Currie, J., Joshua, G.Z. and Katherine, M. (2013). Something in the Water: Contaminated Drinking Water and Infant Health. Canadian Journal of Economics. 2013;46(3): 791- 810.

x. Emoabino, I.U. and Alayande, A.W. (2007). Water DemandManagement, Problems and Prospects of Implementationsin Nigeria. Practices on River Basin Management,pp 154-159.

xi. $\quad$ Federal Capital Development Authority (1980) Gwagwalada Master Plan. Printed by JAH ADSOH Ltd. Lagos.

xii. Federal Ministry of Environment. National Standard for Drinking Water Quality (NSDWQ) (1991)“National Interim Guidelines and Standards for Industrial Effluents, Gaseous Emissions and Hazardous Wastes.”Abuja, Nigeria

xiii. Goudarzi, S. (2015). Transporting Samples: Run Your Lab Like A Business. Lab Manager. Vol. 10 No. 1.

xiv. Horne, A. J., and Goldman, C. R. 1994. Limnology, 2ndedition. McGraw-Hill, Inc. 576 pp.

Xv. Ishaya, S. and Abaje, I. B. (2009). Assessment ofBore Wells Water Quality in Gwagwalada

town of FCT. Journal of Ecology and Natural Environment 1(2): 032-036.

xvi. Kayode O.T.; Okagbue, H.I. and Achuka, J.A. (2018). Water Quality Assessment for Groundwater around Municipal Waste. ElsevierData in Brief 17(2018)579-587

xvii. Klotz, K., Weistenhöfer, W., Neff, F., Hartwig, A., van Thriel, C., and Drexler, H. (2017). The Health Effects of Aluminium Exposure. Deutsches Arzteblatt international, 114(39), 653-659. doi:10.3238/arztebl.2017.0653

xviii. Krishnan, S. and Indu, R. (2006) Groundwater Contamination in India: Discussing Physical Processes, Health and Socio-behavioural Dimensions. IWMI-Tata, Water Policy Research Programmes, Anand, India. 2006.

xix. Lentech, (2009). Drinking Water Standards. Lentech Water Treatment and Purification Holding BV (19982009). Retrieved from: www.who.eu-water standards.html.

xx. Levallois, P., Barn, P., Valcke, M., Gauvin. D., Kosatsky, T. (2018). Public Health Consequences of Lead in Drinking Water.Curr Environ Health Rep. 5(2):255-262. doi: 10.1007/s40572-018-0193-0.

xxi. Makwe, E. (2013) The Impact of Population Growth on Water Supply in Gwagwalada Town, Federal Capital Territory, Abuja. Journal of Sustainable Development in Agriculture and Environment. Vol. 7(1)56-64. http://www.josdae.org/index.php/volume?layout=edit\&id=90

xxii. Makwe, E. and Chup, C.D. (2013a) Analysis of Surface Water Pollution from Karu Abattoir Effluents, Abuja, Nigeria. International Journal of Agricultural Economics, Rural $\quad$ Sociology and Development. Vol. 5(1) 29-42

xxiii. Makwe, E. and Chup, C.D. (2013b) Seasonal Variation in Physico-Chemical Properties of Groundwater around Karu Abattoir. Ethiopian Journal of Environmental Studies and Management. Vol. 6(5) 489497.http://dx.doi.org/10.4314/ejesm.v6i5.6

xxiv. Makwe, E. (2020) Assessment of the Environmental and Health Effects of Solid Mineral Mining in Ebonyi State, Nigeria.A PhD Thesis submitted to the Department of Geography, University of Nigeria, Nsukka

xxv. Merem, E. C., Twumasi, Y., Wesley, J., Isokpehi, P., Shenge, M., Fageir, S., Crisler, M., Romorno, C., Hines, A., Hirse, G., Ochai, S., Leggett, S. and Nwagboso, E. (2017), Assessing the Ecological Effects of Mining in West Africa: The Case of Nigeria. International Journal of Mining Engineering and Mineral Processing.6(1): 1-19. doi:10.5923/j.mining.20170601.01.

xxvi. Nel, L.H. and Markotter, W. (2009) New and Emerging Waterborne Infectious Diseases. Encyclopaedia of Life Support System.2009; 1:1-10.

xxvii. Ntengwe, F.W.(2005). Designing a Domestic Water Supply System-The Engineer's Perspective and Considerations as a Challenge to Consumers. Physics Chem. Earth, 30,(11-16):850-858.http://ewb uiuc.org/system/files/sdarticle.pdf

xxviii. Ocheri, M.I., Odoma, L.A. and Umar, N.D. (2014) Groundwater Quality i Nigerian Urban Areas: A Review. Global Journal of Science Frontier Research, 14, 35-46.

xxix. Oki, O.A. and Oboshenure, K.K. (2017) Assessment of groundwater potability using Water QualityIndex approach in Tombia Town, Yenagoa, Nigeria. Journal of Multidisciplinary Engineering Science and Technology. 2017; 4(7):7606-7611. 
xxx. Oyem, H. H., Oyem, I. M., and Usese, A. I. (2015). Iron, Manganese, Cadmium, Chromium,

Zinc and Arsenic Groundwater Contents of Agbor and Owa Communities of Nigeria. SpringerPlus, 4, 104. doi:10.1186/s40064015-0867-0

xxxi. Sengupta P. (2013). Potential Health Impacts of Hard Water. International Journal of Preventive Medicine, 4(8), 866-875.

xxxii. Singh, S., Mosley, L.M. (2003). Trace metal levels in drinking water on Viti Levu, Fiji Islands. South Pacific Journal of Natural Sciences, 2003, 21:31-34.

xxxiii. Soylak, M.; Armagan Aydin, F.; Saracoglu, S.; Elci, L. and Dogan, M. (2002). Chemical Analysis of Drinking Water Samplesfrom Yozgat, Turkey.Polish Journal of Environmental Studies Vol. 11, No. 2 (2002), 151-156

xxxiv. Ullah, S., Javed, M.W. and Shafique, M. (2014). An integratedapproach for quality assessment ofdrinking water usingGIS: A case study of Lower Dir. Journal of Himalayan Earth $\quad$ Sciences. 2014;47(2):163-74

xxxv. WHO (2003a) pH in Drinking-Water. Background Document for Development of WHO Guidelinesfor Drinkingwater Quality 2003.Originally Published in Guidelines for drinking-water quality, 2nd ed. Vol. 2. Health criteria and other supporting information. World Health Organization, Geneva.

xxxvi. WHO (2003b) Sodium in Drinking-water. Background document for development of WHO Guidelinesfor Drinking-water Quality.Originally published in Guidelines for drinking-water quality, 2nd ed. Vol. 2. Health criteria and other supporting information. World Health Organization, Geneva, 1996.

xxxvii. WHO (2004) Guidelines for Drinking Water Quality W.H.O. Geneva?

xxxviii. WHO (2004b) Sulphate in Drinking-Water. Background Document for Development of WHO Guidelinesfor Drinking-water Quality (WHO 2004)

xxxix. WHO (2008).Guidelines for Drinking Water Quality, 3rd ed. Vol 1. Incorporating the First andSecond Addenda, WHO, Geneva (2008): ISBN 978924154761

xl. WHO/UNICEF (2010). Joint Monitoring Programme for Water Supply and Sanitation. Progress on Sanitation and Drinking-water: 2010 Update.World Health Organization, 20 Avenue Appia, 1211 Geneva 27, Switzerland 50

xli. World Health Organization, (2012). Guidelines for Drinking Water. (2nd edition) Vol. 2. Health Criteria and other Supporting Information. Geneva, Switzerland; World Health Organization (WHO), pp. 940-949.

xlii. WHO (2015) Sanitation, Drinking Water and Hygiene. Status Overview. UN-Water Global Analysis and Assessment of Sanitation and Drinking

xliii. WHO, 2019 Lead Poisoning and Health Accessed online @ www:

https://www.who.int/ipcs/lead_campaign/objectives/en/ https://apps.who.int/iris/bitstream/handle/10665/326646/WHO-CED-PHE-EPE-19.5- eng.pdf?ua=1

xliv. Willhite, C.C., Karyakina, N.A., Yokel, R.A., Yenugadhati, N., Wisniewski, T.M., Arnold, I.M., Momoli, F., Krewski, D. (2014) Systematic review of potential health risks posed by pharmaceutical, occupational and consumer exposures to metallic and nanoscale aluminium, aluminium oxides, aluminium hydroxide and its soluble salts. Crit Rev Toxicol. 44:1-80.

xlv. Yusuf, K. A. (2007). Evaluation of Ground Water Characteristics in Lagos City. Journal of Applied Sciences 7(13):1780-1784 